\title{
Originals
}

\section{Insulinoma cells in culture show pronounced sensitivity to alloxan- induced oxidative stress}

\author{
H.Zhang, K. Öllinger, U. Brunk \\ Department of Pathology II, Faculty of Health Sciences, Linköping University, Linköping, Sweden
}

\begin{abstract}
Summary In a model system of cultured J-774 cells we have previously shown that alloxan in moderate concentrations is toxic only in the presence of a reducing agent with the production of hydrogen peroxide. The cytotoxicity was found to involve lysosomal destabilization. In the present study the cytotoxic effects of (i) alloxan alone, (ii) a combination of alloxan and cysteine or (iii) hydrogen peroxide were investigated in two established insulinoma cell lines (HITT15 and RINm5F), and compared with the effects on J-774 cells. The protective effects of desferrioxamine and catalase, and the intracellular levels of reduced glutathione and activities of the enzymes glutathione peroxidase, glutathione reductase and catalase were also studied. HIT and RIN cells showed about 10 times greater sensitivity than $\mathrm{J}-774$ cells against exposure to either alloxan and cysteine, or hydrogen peroxide. All cell types were relatively insensitive to
\end{abstract}

alloxan alone. Preincubation with desferrioxamine and addition of catalase provided efficient protection against cytotoxicity and lysosomal destabilization. HIT and RIN cells had less capacity to degrade hydrogen peroxide and lower levels of glutathione peroxidase than J-774 cells. The lysosomal stability in all three cell lines was directly correlated to their viability. We conclude that HIT and RIN cells have weak antioxidative defence systems resulting in enhanced lysosomal vulnerability when they are exposed to alloxan and cysteine, which produce hydrogen peroxide extracellularly. The degree of cytotoxicity seems to be dependent on cellular capacity to degrade hydrogen peroxide and the lysosomal content of reactive iron. [Diabetologia (1995) 38: 635-641]

Key words Alloxan, hydrogen peroxide, insulinoma cells, lysosomes, oxygen radicals.
Many types of cells including, and above all, the pancreatic islet beta cells, are vulnerable to the cytotoxic effects of alloxan [1-7]. Alloxan can also cause dam-

Received: 12 August 1994 and in revised form: 28 November 1994

Corresponding author: Dr. H. Zhang, Department of Pathology II, Faculty of Health Sciences, Linköping University, S58185 Linköping, Sweden

Abbreviations: AO, Acridine orange; Des, desferrioxamine; GSH, reduced glutathione; GSHPx, glutathione peroxidase; GSHRed, glutathione reductase; GSSG, oxidized glutathione; HIT-T15 (HIT), an established hamster insulinoma cell line; $\mathrm{HO}$, hydroxyl radical; $\mathrm{H}_{2} \mathrm{O}_{2}$, hydrogen peroxide; HPLC, high performance liquid chromatography; $\mathrm{LD}_{50}$, median lethal dose; $\mathrm{O}_{2}{ }^{-}$, superoxide anion radical; $\mathrm{PBS}$, Dulbecco's phosphate-buffered saline, $\mathrm{pH} 7.4$ without $\mathrm{Ca}^{2+}$ and $\mathrm{Mg}^{2+}$; RINm5F (RIN), an established rat insulinoma cell line. age to erythrocytes [8], hepatocytes [9], fibroblasts [10], salivary gland cells [11] and macrophages [1215]. The precise mechanisms of the alloxan cytotoxicity are still not known in detail, although reactive oxygen species have been suggested to be important mediators during the cytotoxic process $[3,4,7,10$, 12-20]. The proposed cellular targets of alloxan cytotoxicity include plasma membranes $[2,8]$, mitochondria [5], DNA [7] and lysosomes [12-15]. Alloxan is easily reduced by a variety of reductants to dialuric acid, which is oxidized back to alloxan in the presence of oxygen with the formation of alloxan radicals and superoxide anion radicals $\left(\mathrm{O}_{2}{ }^{-}\right)$. The latter are eventually dismutated to hydrogen peroxide $\left(\mathrm{H}_{2} \mathrm{O}_{2}\right)$ [16-19], which is potentially harmful because of its capacity to react with catalytically active ferrous iron to form hydroxyl radicals ( $\mathrm{HO}^{\circ}$ ) [3, 4, 21-23]. 
We have previously shown, using a model system of cultured J-774 cells [12-15], that alloxan is readily reduced by cysteine, ascorbic acid or reduced glutathione $(\mathrm{GSH})$, with the formation of $\mathrm{H}_{2} \mathrm{O}_{2}$. Moreover, the cytotoxic effect of alloxan was found to depend on the extracellular production of $\mathrm{H}_{2} \mathrm{O}_{2}$, which diffuses through the plasma and lysosomal membranes and initiates intralysosomal iron-catalysed reactions that destabilize the lysosomal membranes with ensuing cell degeneration. The alloxan/reducing agent cytotoxicity was efficiently abolished by preincubation of cells with desferrioxamine (Des), which is endocytosed [24] and accumulated intralysosomally, thus proving the importance of intralysosomal iron-catalysed oxidative reactions [22]. The cytotoxicity of alloxan in combination with a reducing agent is also abolished by the addition of catalase, demonstrating the importance of extracellularly formed $\mathrm{H}_{2} \mathrm{O}_{2}$ in alloxan cytotoxicity $[12,13,15]$.

The glutathione redox cycle, catalysed by glutathione peroxidase (GSHPx) [25] and glutathione reductase (GSHRed) activity, is considered to be a key step in cellular $\mathrm{H}_{2} \mathrm{O}_{2}$ breakdown. Therefore, we speculated that the sensitivity of cells to alloxan-induced oxidative stress might depend on (i) the balance between the extracellular production of $\mathrm{H}_{2} \mathrm{O}_{2}$ and the capacity of intracellular antioxidative defence systems to prevent the influx of $\mathrm{H}_{2} \mathrm{O}_{2}$ into lysosomes and (ii) the lysosomal content of catalytically active iron.

In the present study the evaluation of the cytotoxic effect of alloxan-induced oxidative stress was extended to cultured insulinoma cells and the findings compared to those of our previous J-774 cell model system in order to find out whether the above suggested mechanisms also operate in cell types of more direct relevance to the understanding of alloxan-induced pancreatic islet beta-cell damage.

\section{Materials and methods}

Chemicals and culture media. RPMI 1640 culture medium (RPMI), Ham's F-10 culture medium F-10), fetal calf serum (FCS), L-glutamine $(200 \mathrm{mmol} / \mathrm{l})$, penicillin-G (5000 IU/ml) and streptomycin $(5000 \mu \mathrm{g} / \mathrm{ml})$ were from GIBCO BRL (Paisley, Scotland, UK). Alloxan was from Biochemical BDH Ltd. (Poole, Dorset, UK) and $\mathrm{H}_{2} \mathrm{O}_{2}$ from Aldrich-Chemic (Steinheim, Germany). L-cysteine and acridine orange (AO) were obtained from Sigma (St Louis, Mo., USA) and Des was from Ciba-Geigy AG (Basel, Switzerland). Catalase, GSH, GSHRed and NADPH were from Boehringer (Mannheim, Germany). All other chemicals were of analytical grade and obtained from standard sources.

Cells and culture conditions. HIT-T15 (passage numbers 90120) [26] and RINm5F (passage numbers 30-75) [27] insulinoma cells were maintained in $75-\mathrm{cm}^{2}$ plastic cell culture flasks (Costar, Cambridge, Mass., USA) with $15 \mathrm{ml}$ RPMI containing $10 \% \mathrm{FCS}, 2 \mathrm{mmol} / 1 \mathrm{~L}$-glutamine, $100 \mathrm{IU}$ penicillin-G and
$100 \mu \mathrm{g} / \mathrm{ml}$ streptomycin. J-774 cells were cultured in F-10 supplemented with $10 \% \mathrm{FCS}, 2 \mathrm{mmol} / \mathrm{l}$ L-glutamine, $100 \mathrm{IU}$ penicillin-G and $100 \mu / \mathrm{ml}$ streptomycin. All three cell types were grown at $37^{\circ} \mathrm{C}$ in humidified $95 \%$ air with $5 \% \mathrm{CO}_{2}$ and subcultivated weekly, HIT and RIN cells by the EGTA-trypsin technique and J-774 cells by scraping with a rubber policeman. Throughout the cell growth period the culture media were replaced every $48 \mathrm{~h}$.

Experimental conditions. All experiments were performed on cultured HIT, RIN and J-774 cells in $35 \mathrm{~mm}$ Petri dishes ( $2 \times 10^{5}$ cells/dish $\pm 22 \mathrm{~mm}$ round glass coverslip) and 12-well multiplates $\left(10^{5}\right.$ cells/well $)$. Cells were subcultivated under ordinary culture conditions for $24 \mathrm{~h}$ before the initiation of experiments. To avoid interference from reductive or oxidative substances in culture medium [14] experiments were carried out in Dulbecco's phosphate-buffered saline, $\mathrm{pH} 7.4$ without $\mathrm{Ca}^{2+}$ and $\mathrm{Mg}^{2+}$ (PBS) at $37^{\circ} \mathrm{C}$. The concentrations of alloxan, cysteine, and $\mathrm{H}_{2} \mathrm{O}_{2}$ were decided according to principles described previously [12-15]. Stock solutions of $100 \mathrm{mmol} / \mathrm{l}$ Des in distilled water were stored at $4^{\circ} \mathrm{C}$ for not more than 2 weeks before use. Hydrogen peroxide $(100 \mathrm{mmol} / \mathrm{l})$ stock solution was prepared daily in distilled water and further diluted in PBS to final concentrations. Alloxan, cysteine and catalase were dissolved in PBS immediately before each experiment in concentrations stated in the figure legends. Cells were exposed to (i) alloxan; (ii) alloxan and cysteine; or (iii) $\mathrm{H}_{2} \mathrm{O}_{2}$. Some cultures were preincubated with $1 \mathrm{mmol} / 1 \mathrm{Des}$ under ordinary culture conditions for $60 \mathrm{~min}$ and others were pretreated with $50 \mu \mathrm{g} / \mathrm{ml}$ catalase in PBS at $37^{\circ} \mathrm{C}$ for $20 \mathrm{~min}$. In the latter experiments $50 \mathrm{mg} / \mathrm{ml}$ catalase was also present during the exposure to alloxan and cysteine. Des $(100 \mu \mathrm{mol} / \mathrm{l})$ was always present $[12,15]$ when cells were exposed to alloxan and cysteine or $\mathrm{H}_{2} \mathrm{O}_{2}$ to block the possible extracellular formation of $\mathrm{HO}^{\circ}$ owing to contaminating iron.

Estimation of cell viability. Viability was estimated by a modified (postponed) version of the trypan blue dye exclusion test [28]. After experimental treatment cells were, therefore, incubated for another $5 \mathrm{~h}$ under ordinary culture conditions and then stained with $0.05 \%$ trypan blue in PBS at $22^{\circ} \mathrm{C}$ for $5 \mathrm{~min}$. Stained and unstained cells were counted using an inverted Nikon microscope (at $\times 250$ ) in 10 randomly selected areas. Cell viability was expressed as percentage of unstained (surviving) cells.

Evaluation of lysosomal membrane stability. Cells grown on coverslips were incubated in complete medium with $5 \mu \mathrm{g} / \mathrm{ml}$ AO under ordinary culture conditions for $15 \mathrm{~min}$, followed by a quick rinse in $\mathrm{PBS}$ at $37^{\circ} \mathrm{C}$. The $\mathrm{AO}$-loaded cells were then exposed to alloxan and cysteine or $\mathrm{H}_{2} \mathrm{O}_{2}$ for the indicated periods of time. Coverslips were inverted onto two-well micro culture slides, filled with PBS at $22^{\circ} \mathrm{C}$. Lysosomal membrane stability was evaluated by simultaneously measuring both red and green fluorescence intensities from 100 randomly chosen cells using a Leitz MPV III photometer microscope with a BG 12 activating filter, a $630-\mathrm{nm}$ barrier filter and a $572-\mathrm{nm}$ interference filter as described previously $[29,30]$

Degradation of hydrogen peroxide. Cells $\left(2 \times 10^{5}\right)$ grown in 35 $\mathrm{mm}$ Petri dishes were exposed to $50 \mu \mathrm{mol} / 1 \mathrm{H}_{2} \mathrm{O}_{2}$ in PBS $(2 \mathrm{ml} /$ dish) at $37^{\circ} \mathrm{C}$. $\mathrm{H}_{2} \mathrm{O}_{2}$-degradation by HIT, RIN and J-774 cells was assayed by measuring the fluorescence produced by pHPA through $\mathrm{H}_{2} \mathrm{O}_{2}$-dependent oxidation of pHPA to its fluorescent dimer [31]. The degradation of $\mathrm{H}_{2} \mathrm{O}_{2}$ was followed for up to $60 \mathrm{~min}$. Fluorescence intensity was read at $\lambda_{\mathrm{ex}} 315 \mathrm{~nm}$ and $\lambda_{\mathrm{em}} 410 \mathrm{~nm}$ with a RF-540 spectrofluo 
photometer (Shimadzu, Japan) connected to a DR-3 Data recorder.

Determination of iniracellular GSH. Cells $\left(10^{6}\right.$ cells/dish) subcultivated in $35-\mathrm{mm}$ Petri dishes for $24 \mathrm{~h}$ were used for measurement of intracellular GSH by HPLC [32]. In brief, culture medium was withdrawn and dishes were placed at $-18^{\circ} \mathrm{C}$ for $5 \mathrm{~min}$. A solution $(300 \mu \mathrm{l})$ of $0.5 \mathrm{~mol} / \mathrm{l}$ perchloric acid supplemented with $1 \mathrm{mmol} / \mathrm{LDTA}$ was added to each dish and the samples were then collected in test tubes on ice with a plastic cell scraper and centrifuged at $2000 \mathrm{rev} / \mathrm{min}$ for $10 \mathrm{~min}$. The supernatant was withdrawn for GSH analysis and the pellet was dissolved in $300 \mu \mathrm{l} 1 \mathrm{~mol} / 1 \mathrm{NaOH}$ for protein assay with the method described by Lowry et al. [33]. GSH was analysed on a Kromasil 100-5C18 (Hichrom, Reading, UK) reverse phase column $(250 \times 4.6 \mathrm{~mm})$ with a mobile phase consisting of $0.1 \mathrm{~mol} / 1 \mathrm{NaH}_{2} \mathrm{PO}_{4}, 0.1 \mathrm{mmol} / \mathrm{l}$ EDTA, $0.02 \mathrm{mmol} / \mathrm{ln}$-octyl sodium sulphate and $5 \%$ methanol and detected using an LC-4B Amperiometric detector (BAS, Inc., West Lafayette, Ind., USA) equipped with a gold electrode at $+0.5 \mathrm{~V}$ potential. The mobile phase was supplied by a ConstaMetric III pump at $0.5 \mathrm{ml} / \mathrm{min}$ flow rate. The retention time for $\mathrm{GSH}$ was $11 \mathrm{~min}$. The concentration of intracellular GSH was calculated from a standard curve and represented as nmol per mg protein.

Measurement of glutathione peroxidase, glutathione reductase and catalase activities. HIT and RIN cells $\left(10^{6} /\right.$ dish $\left.\times 5\right)$ were detached with $0.25 \%$ trypsin for $3 \mathrm{~min}$, whereas J-774 cells were obtained by scraping with a plastic scraper. The cells were washed twice in ice cold PBS and then treated by three cycles of freezing and thawing to rupture the plasma membranes. Glutathione peroxidase [34] and glutathione reductase [35] activities were analysed spectrophotometrically using a Varian DMS-100 spectrophotometer (Varian AB, Solna, Sweden) at $340 \mathrm{~nm}\left(37^{\circ} \mathrm{C}\right)$, and expressed as $\mu \mathrm{mol} / 1 \mathrm{NADPH}$ oxidized/min and $\mathrm{mg}$ protein. Both selenium-dependent and selenium-independent GSHPx activity were determined by using t-butyl hydroperoxide as substrate. All reagents except the cell material were included in blanks in order to correct for NADPH oxidation by the peroxide (i.e. non-enzymatic oxidation). Catalase activity [36] was measured spectrophotometrically at $240 \mathrm{~nm}\left(25^{\circ} \mathrm{C}\right)$ and the activity was expressed as $\mu \mathrm{mol}$ $\mathrm{H}_{2} \mathrm{O}_{2}$ consumed/min and mg protein.

\section{Statistical analysis}

Experiments were done in triplicate unless otherwise noted. All values are presented as mean \pm SEM. Student's $t$-test was utilized for evaluation of statistical significance of differences between experimental and control groups. $p$-values less than 0.05 were considered significant.

\section{Results}

Cytotoxic effects of alloxan alone. HIT, RIN and J-774 cells were exposed to alloxan $(0-20 \mathrm{mmol} / \mathrm{l})$ for 60 min. As shown in Figure 1, HIT, and RIN cells were about 1.5 times more sensitive to alloxan than $\mathrm{J}-774$ cells. The median lethal dose $\left(\mathrm{LD}_{50}\right)$ of alloxan to HIT, RIN and J-774 cells were $8,8.5$ and 14 (mmol/l), respectively. Almost $80 \%$ of the HIT and RIN cells died after exposure to $10 \mathrm{mmol} / \mathrm{l}$ alloxan

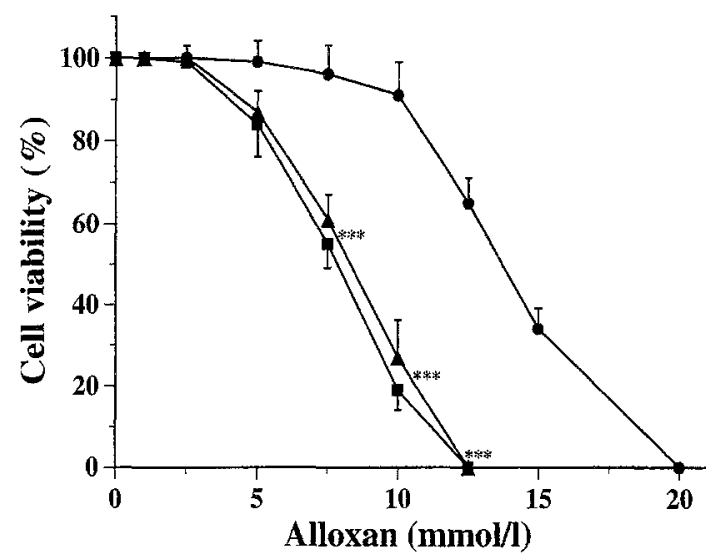

Fig. 1. Viability (postponed trypan blue dye exclusion test) of HIT ( $\boldsymbol{\square})$, RIN ( $\boldsymbol{\Delta}$ ) and J-774 (•) cells exposed to alloxan alone $(0-20 \mathrm{mmol} / \mathrm{l})$ in PBS at $37^{\circ} \mathrm{C}$ for $60 \mathrm{~min}$, followed by a rinse in PBS at $37^{\circ} \mathrm{C}$ and another $5 \mathrm{~h}$ under ordinary culture conditions. $* * * p<0.001$ compared to that of $\mathrm{J}-774$ cells. Data are given as mean values $\pm \operatorname{SEM}(n=3)$

for 60 min, while fewer than $10 \%$ of the J-774 cells died under the same conditions. (Alloxan is not stable at $\mathrm{pH} 7.4$ and $37^{\circ} \mathrm{C}$ for more than a few minutes. The prolonged 60-min exposure before evaluation of viability was chosen in order to allow enough expression of cytotoxicity for the trypan blue dye exclusion test).

Cytotoxic effects of alloxan and cysteine. HIT, RIN and J-774 cells were exposed to alloxan/cysteine for up to $60 \mathrm{~min}$. As shown in Figure 2, HIT and RIN cells were about 10 times more sensitive than J-774 cells. Almost all HIT and RIN cells were killed after exposure to $200 \mu \mathrm{mol} / 1$ alloxan and $100 \mu \mathrm{mol} / \mathrm{l}$ cysteine for $60 \mathrm{~min}$, whereas only $50 \%$ of the J-774 cells died, although the latter were exposed to a 10 times higher concentration of alloxan $(2 \mathrm{mmol} / \mathrm{l})$ and cysteine $(1 \mathrm{mmol} / \mathrm{l})$.

The cytotoxic effects of alloxan/cysteine on all three cell types were completely abolished by preincubation with $1 \mathrm{mmol} / \mathrm{l}$ Des, or by pretreatment and the continuous presence of $50 \mu \mathrm{g} / \mathrm{ml}$ catalase (Fig. 2). The $\mathrm{LD}_{50}$ values against HIT, RIN and J-774 cells were $150 / 100,200 / 100$, and 2,000/900 ( $\mu \mathrm{mol} / \mathrm{l})$, respectively.

Lysosomal membrane stability. AO-loaded HIT, RIN and J-774 cells grown on coverslips were exposed to alloxan/cysteine for up to $30 \mathrm{~min}$. The intensity of $\mathrm{AO}$-induced red and green fluorescence was measured. In HIT cells the red AO fluorescence, representing $\mathrm{AO}$ within the acidic lysosomal vacuome, declined and the green fluorescence, representing cytosolic AO, increased, which indicates a loss of the proton gradient across the lysosomal membranes (Fig. 3). The results with AO-loaded RIN cells were the same as those with HIT cells (data not shown). J-774 cells, however, required 10 times higher concentration of 


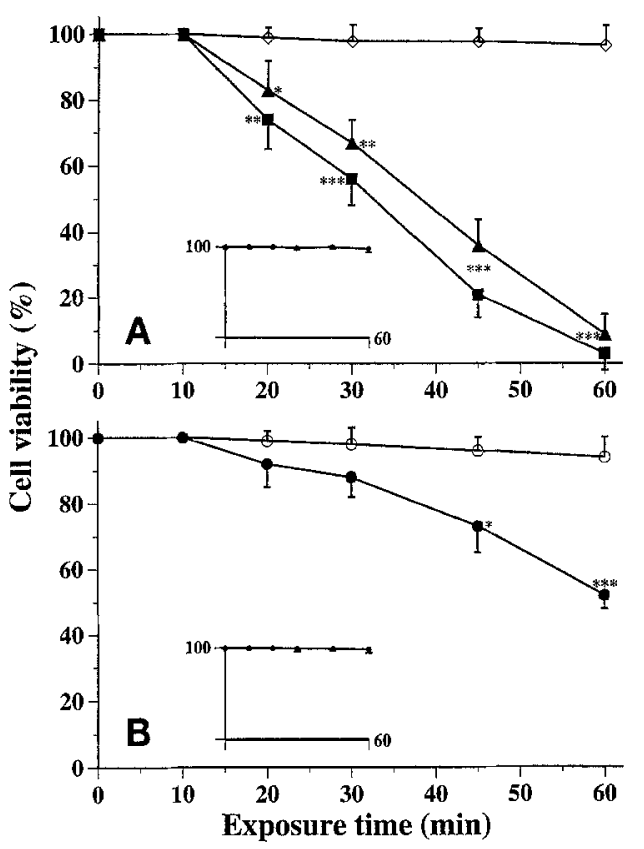

Fig. 2. (A, B) Viability (test as described in Fig. 1) after the exposure of HIT ( $\boldsymbol{G}$ ) and RIN ( $\mathbf{A}$ ) cells to $200 \mu \mathrm{mol} / \mathrm{l}$ alloxan and $100 \mu \mathrm{mol} / 1$ cysteine $(\mathbf{A})$; and of $\mathbf{J}-774$ (•) cells to 10 times higher concentrations $(2 \mathrm{mmol} / 1$ alloxan and $1 \mathrm{mmol} /$ 1 cysteine) (B) in PBS at $37^{\circ} \mathrm{C}$ for up to $60 \mathrm{~min}$. Open symbols indicate that the cells $(\diamond, \mathrm{HIT} / \mathrm{RIN} ; 0, \mathrm{~J}-774)$ were initially preincubated with $1 \mathrm{mmol} / 1$ Des for $60 \mathrm{~min}$. Inserts show the protective effects on alloxan/cysteine cytotoxicity by the addition of $50 \mu \mathrm{g} / \mathrm{ml}$ catalase during the exposure. ${ }^{*} p<0.05$; $* * p<0.01 ; * * * p<0.001$ compared to the cells preincubated with Des and then exposed to alloxan/cysteine. The latter cells show no deviation from controls exposed to PBS only (not shown). Data are given as mean values $\pm \operatorname{SEM}(n=3)$

alloxan/cysteine to show a similar shift of AO fluorescence. Preincubation with Des completely prevented AO relocalization in all cell types.

Cytotoxic and lysosomal effects of hydrogen peroxide. As shown in Figure 4, almost all the HIT and RIN cells died after exposure to $50 \mu \mathrm{mol} / 1 \mathrm{H}_{2} \mathrm{O}_{2}$ for $60 \mathrm{~min}$ but only about $40 \%$ of the J-774 cells died when they were exposed to $500 \mu \mathrm{mol} / 1 \mathrm{H}_{2} \mathrm{O}_{2}$. The killing was prevented for all three cell types by preincubation with Des before exposure to $\mathrm{H}_{2} \mathrm{O}_{2}$. $\mathrm{LD}_{50}$ of $\mathrm{H}_{2} \mathrm{O}_{2}$ to HIT and RIN cells was $45 \mu \mathrm{mol} / \mathrm{l}$ and $30 \mu \mathrm{mol} / 1$, respectively, while it was $550 \mu \mathrm{mol} / 1$ for $\mathrm{J}$ 774 cells after 60 -min exposure.

When AO-loaded HIT (Fig.5) and RIN (data not shown) cells were exposed to $50 \mu \mathrm{mol} / 1 \mathrm{H}_{2} \mathrm{O}_{2}$ for up to $60 \mathrm{~min}$, the red fluorescence declined, whereas the green fluorescence markedly increased. The AO relocalization was prevented by preincubation in $1 \mathrm{mmol} / 1 \mathrm{Des}$ under ordinary culture conditions for $60 \mathrm{~min}$ before the exposure.

Degradation of hydrogen peroxide. Degradation of $\mathrm{H}_{2} \mathrm{O}_{2}(50 \mu \mathrm{mol} / \mathrm{l})$ in PBS by HIT, RIN and J-774 cells

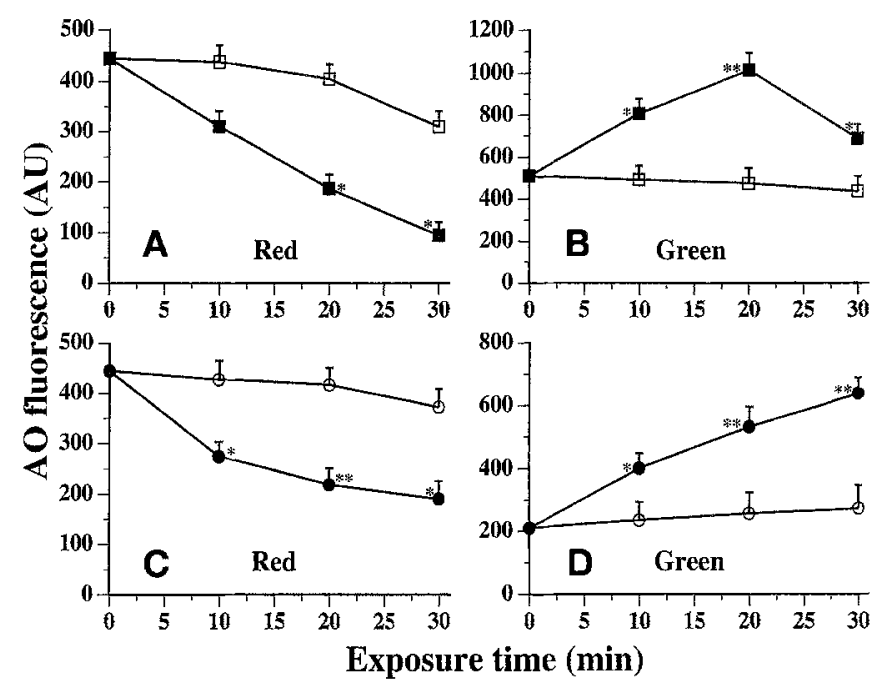

Fig. 3. (A-D) Shift of AO-induced red (A and $\mathbf{C})$ and green (B and $\mathbf{D})$ fluorescence after the exposure of AO-loaded HIT and J-774 cells to alloxan/cysteine. HIT cells ( $\boldsymbol{D})(\mathbf{A}$ and $\mathbf{B}$ ) were exposed to $200 \mu \mathrm{mol} / \mathrm{l}$ alloxan and $100 \mu \mathrm{mol} / 1$ cysteine; and $\mathbf{J}$ 774 cells ( $)(\mathbf{C}$ and $\mathbf{D})$ to 10 times higher concentrations ( $2 \mathrm{mmol} / 1$ alloxan and $1 \mathrm{mmol} / 1$ cysteine) in $\mathrm{PBS}$ at $37^{\circ} \mathrm{C}$ for up to 30 min. Open symbols indicate that cells ( $\square$, HIT; O, J774) were initially preincubated with $1 \mathrm{mmol} / \mathrm{l}$ Des for $60 \mathrm{~min}$ at ordinary culture conditions. * $p<0.05$; ** $p<0.01$ compared to the cells preincubated with Des and then exposed to alloxan/cysteine. The latter cells show no deviation from controls exposed to PBS only (not shown). Data are given as mean values \pm SEM $(n=3)$

was determined at $37^{\circ} \mathrm{C}$ for up to $60 \mathrm{~min}$. As shown in Figure 6, a rapid degradation of $\mathrm{H}_{2} \mathrm{O}_{2}$ was recorded during the first $5 \mathrm{~min}$ for all three cell types. The degradation rates then leveled off, especially with the HIT and RIN cells.

Intracellular concentration of GSH. Intracellular GSH concentration was analysed by HPLC on cells grown under ordinary culture conditions for $24 \mathrm{~h}$ after subcultivation. The mean values were $22.4 \pm 2.4,10.6 \pm 2.5$ and $27.1 \pm 2.5 \mathrm{nmol} / \mathrm{mg}$ protein for HIT, RIN and J-774 cells, respectively $(n=3)$. The level of GSH in RIN cells was significantly lower than that of HIT $(p<0.01)$ or J-774 $(p<0.001)$ cells.

Enzyme activities. The activities of the enzymes (GSHPx, GSHRed and catalase) were analysed in the three cell lines. As shown in Table 1, the GSHPx was significantly lower in HIT $(p<0.001)$ and RIN $(p<0.001)$ cells as compared to J-774 cells. The activity of the other $\mathrm{H}_{2} \mathrm{O}_{2}$ consuming enzyme, catalase, was lower in HIT $(p<0.05)$ cells than in J-774 cells although there was no significant difference between RIN and J-774 cells. Glutathione reductase showed lower activity in HIT cells $(p<0.001)$ but higher activity in RIN cells $(p<0.01)$ as compared to $\mathrm{J}$ 774 cells. 


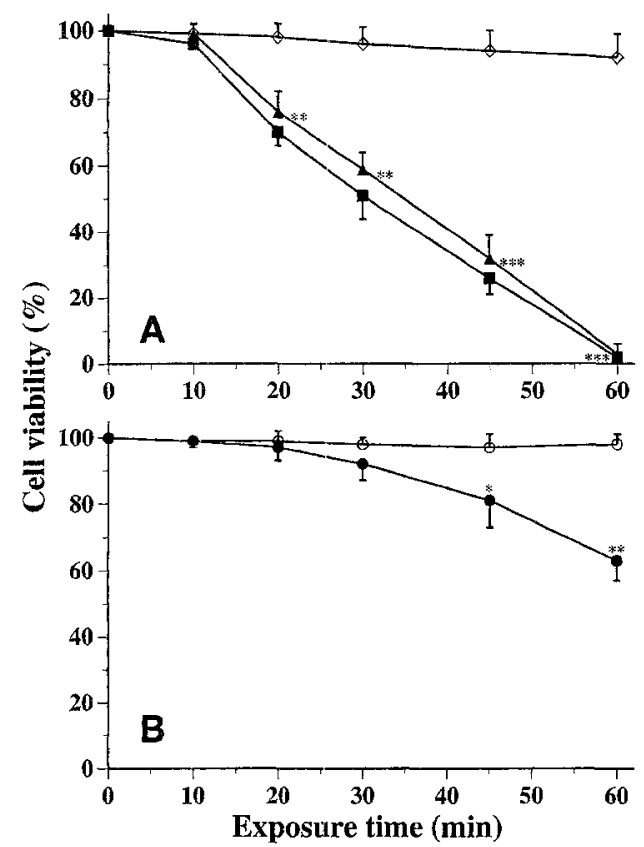

Fig. 4. (A, B) Viability (test as described in Fig. 1) of HIT (a) and RIN (A) cells after exposure to $50 \mu \mathrm{mol} / 1 \mathrm{H}_{2} \mathrm{O}_{2}(\mathbf{A})$; and of $\mathrm{J}-774$ ( ) cells exposed to 10 times higher concentration $\left(500 \mu \mathrm{mol} / 1 \mathrm{H}_{2} \mathrm{O}_{2}\right)(\mathbf{B})$ in $\mathrm{PBS}$ at $37^{\circ} \mathrm{C}$ for up to $60 \mathrm{~min}$. Open symbols indicate that cells $(\diamond$, HIT/RIN; $O$, J-774) were initially preincubated in $1 \mathrm{mmol} / \mathrm{l}$ Des for $60 \mathrm{~min}$ at ordinary culture conditions. $* p<0.05 ; * * p<0.01 ; * * * p<0.001$ compared to the cells preincubated with Des and then exposed to $\mathrm{H}_{2} \mathrm{O}_{2}$. The latter cells show no deviation from controls exposed to PBS only (not shown). Data are given as mean values \pm SEM $(n=3)$

\section{Discussion}

As a quinonoid compound alloxan is readily reduced and autooxidized with the formation of alloxan radicals, superoxide anion radicals and hydrogen peroxide [16-19]. We have previously shown in a model system of cultured J-774 cells that the extracellular formation of hydrogen peroxide, rather than the uptake of alloxan itself, mediates the cytotoxic effects of alloxan [12-15]. Moreover, the cytotoxicity was found to be related to an initial alteration of lysosomal membrane stability induced by iron-catalysed intralysosomal reactions. This suggests that the cellular degeneration that results from the exposure either to alloxan in combination with a reducing agent or to hydrogen peroxide might be due to the release of lysosomal contents, such as hydrolytic enzymes [13-15, 22].

In the present study, comparing two established lines of insulinoma cells (HIT and RIN) with J-774 cells we found the similar basic mechanisms to be operating for all three cell types, although the insulinoma cells were much more vulnerable both to alloxan/reducing agent and to hydrogen peroxide. Therefore, it is again shown that alloxan by itself seems to be non-toxic and requires high concentrations in order to have lethal effects. Under these conditions al-

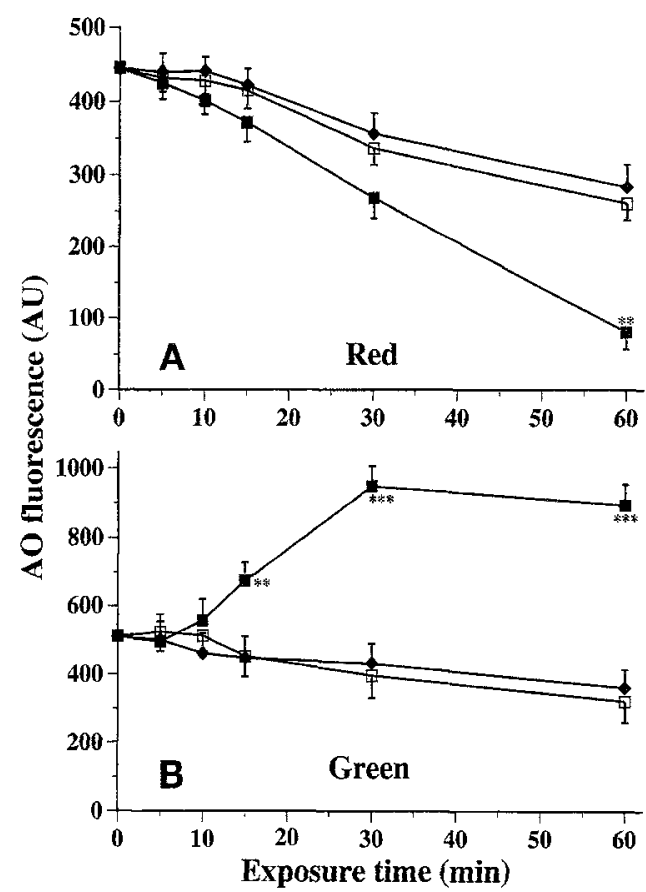

Fig. 5. (A, B) Shift of AO-induced red (A) and green (B) fluorescence of HIT cells ( $\mathbf{D}$ ) after exposure to $50 \mu \mathrm{mol} / 1$ $\mathrm{H}_{2} \mathrm{O}_{2}$ in PBS at $37^{\circ} \mathrm{C}$ for up to $60 \mathrm{~min}$. Open symbols ( $\square$ ) indicate that cells were preincubated in $1 \mathrm{mmol} / 1$ Des for $60 \mathrm{~min}$ under ordinary culture conditions before exposure to hydrogen peroxide. Control cells $(\bullet)$ were exposed to PBS only at $37^{\circ} \mathrm{C}$. $* * p<0.01 ; * * * p<0.001$ compared to the controls. Data are given as mean values $\pm \operatorname{SEM}(n=3)$

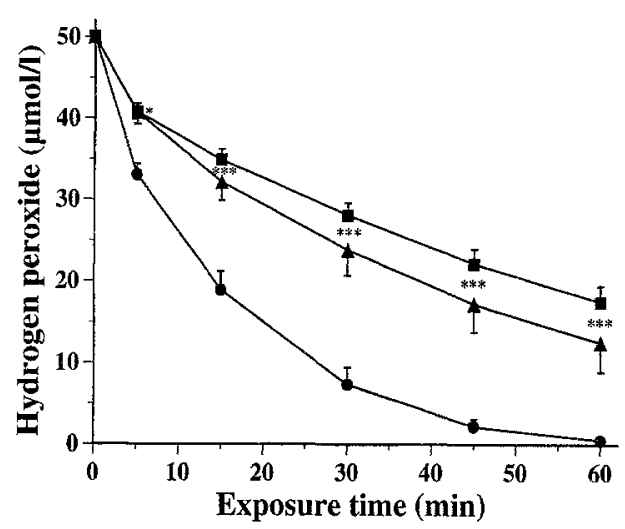

Fig. 6. Degradation of hydrogen peroxide measured with the pHPA/HRP fluorescence technique during the exposure of HIT (ם), RIN ( $\boldsymbol{\Delta})$ and J-774 (•) cells $\left(2 \times 10^{5}\right.$ cells $/$ dish $)$ to $50 \mu \mathrm{mol} / 1 \mathrm{H}_{2} \mathrm{O}_{2}$ in PBS $(2 \mathrm{ml} /$ dish $)$ at $37^{\circ} \mathrm{C}$ for up to $60 \mathrm{~min}$. $* p<0.05 ; * * p<0.01 ; * * * p<0.001$ compared to that of J-774 cells. Data are given as mean values $\pm \operatorname{SEM}(n=3)$

loxan may be taken up by the cells through fluid phase endocytosis or by a receptor-mediated process, and induce the intracellular formation of hydrogen peroxide in toxic amounts owing to the presence of a variety of intracellular reducing substances. The higher endocytotic activity of the macrophage-like J-774 cells compared to the insulinoma cells may explain the small difference in the cytotoxicity of alloxan alone compared to alloxan/reducing agent or hydrogen peroxide. 


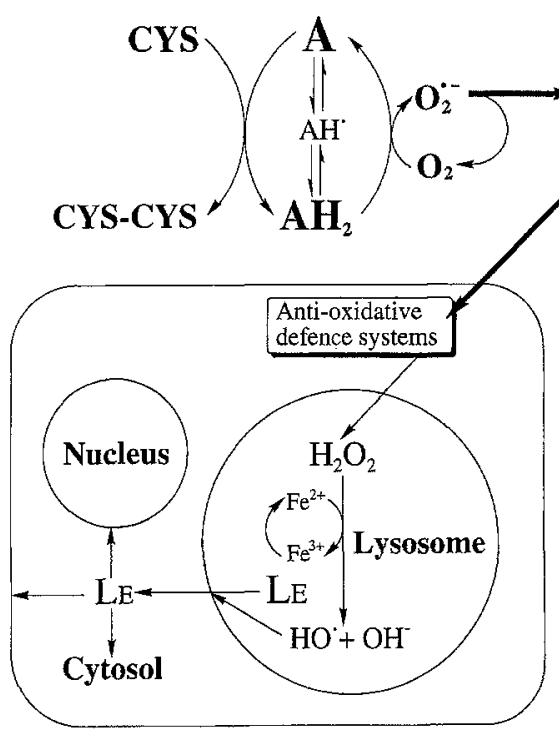

HIT/RIN

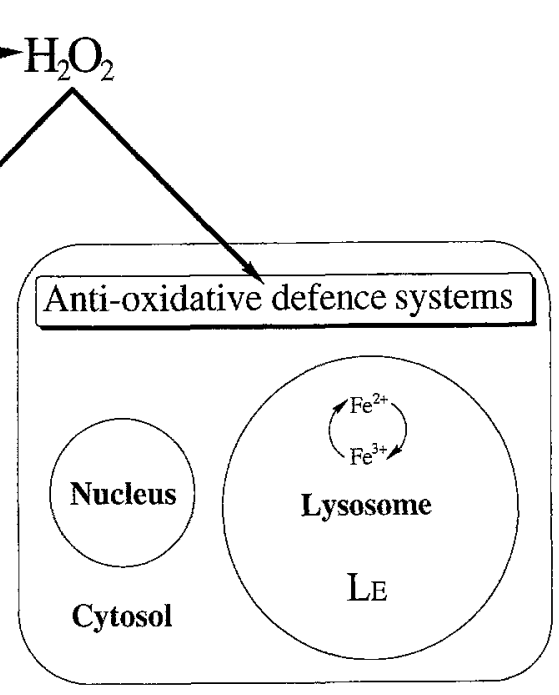

$\mathrm{J}-774$
Fig. 7. Tentative explanation for the different sensitivity between insulinoma and J-774 cells against cytotoxic effects induced by alloxan/cysteine. Alloxan (A) is reduced by the reductant cysteine (CYS) to dialuric acid $\left(\mathrm{AH}_{2}\right)$ with the formation of alloxan radicals (AH.), superoxide anion radicals $\left(\mathrm{O}_{2}^{-}\right)$and hydrogen peroxide $\left(\mathrm{H}_{2} \mathrm{O}_{2}\right)$. The latter is nonpolar and easily diffuses through plasma and lysosomal membranes. If the cells are exposed to hydrogen peroxide in concentrations large enough to break through the antioxidative defence system (mainly GSHPx, catalase and GSH), iron-catalysed intralysosomal reactions will follow and result in the release of lysosomal contents, e.g. enzymes (LE) into the cytosol with ensuing cellular degeneration and death
Table 1. Activities of enzymes (GSHPx, GSHRed and catalase)

\begin{tabular}{lccl}
\hline Cell line & GSHPx $^{\mathrm{a}}$ & GSHRed $^{\mathrm{a}}$ & Catalase $^{\mathrm{b}}$ \\
\hline HIT & $2.3 \pm 0.03^{\mathrm{e}}$ & $4.3 \pm 0.19^{\mathrm{e}}$ & $0.5 \pm 0.03^{\mathrm{c}}$ \\
RIN & $1.3 \pm 0.18^{\mathrm{e}}$ & $35.4 \pm 2.87^{\mathrm{d}}$ & $1.7 \pm 0.05$ \\
$\mathrm{~J}-774$ & $18.8 \pm 1.08$ & $21.7 \pm 1.17$ & $2.3 \pm 0.63$ \\
\hline
\end{tabular}

Enzyme activities were measured as described in the Materials and methods section. ${ }^{a} \mu \mathrm{mol} \mathrm{NADPH} / \mathrm{min}$ and $\mathrm{mg}$ protein; ${ }^{\mathrm{b}} \mu \mathrm{mol} \mathrm{H}_{2} \mathrm{O}_{2} / \mathrm{min}$ and $\mathrm{mg}$ protein. ${ }^{c} p<0.05 ;{ }^{\mathrm{d}} p<0.01$; ${ }^{\mathrm{e}} p<0.001$ compared to $\mathrm{J}-774$ cells. Data are given as mean values $\pm \operatorname{SEM}(n=3)$

The presence of catalase during the exposure to alloxan/reducing agent completely abolished the toxic effects for all three cell types, proving that hydrogen peroxide was the toxic agent rather than alloxan, per se. Moreover, we obtained the same results with hydrogen peroxide as with alloxan/reducing agent in concentrations that give rise to equimolar concentrations of hydrogen peroxide [12].

Not only J-774 cells but also the insulinoma cells showed pronounced lysosomal destabilization after exposure to alloxan/reducing agent or to hydrogen peroxide in concentrations equal to those needed to induce cell death. If the cells were allowed to endocytose the iron chelator desferrioxamine before exposure to alloxan/reducing agent or to hydrogen peroxide all the cells survived otherwise lethal concentrations and showed stable lysosomes with the AO relocalization technique. We thus conclude that secondary lysosomes in all three cell types contain catalytically active iron. This is by no means surprising since autophagocytotic degradation of a variety of metallo-proteins is a normal, continuous phenomenon in all cells. It thus seems reasonable to assume that (i) the cellular capacity to degrade hydrogen per- oxide as well as (ii) the amount of intralysosomal iron in reactive form would be important factors in determining the sensitivity of cells to alloxan/reducing agents or to hydrogen peroxide.

We found that the insulinoma cells degraded hydrogen peroxide less efficiently than J-774 cells. This might be explained by their different activities of hydrogen peroxide-degrading enzymes and different capacity to reduce GSSG back to GSH. HIT cells showed the slowest degradation rate although the level of intracellular GSH was comparable to that of $\mathrm{J}-774$ cells. On the other hand, both hydrogen peroxide consuming enzymes, GSHPx and catalase, showed low activities and the reduction of GSSG by GSHRed was the slowest among the three cell lines. RIN cells showed the lowest activity of GSHPx and the lowest level of intracellular GSH. This cell was, however, more efficient than HIT cells in degrading hydrogen peroxide, but far behind J-774 cells. This might be explained by a more efficient utilization of GSH by RIN cells as compared to HIT cells since GSHRed showed the highest activity of the studied cell lines. RIN cells also had three-fold higher activity of catalase as compared to the HIT cells.

In summary, insulinoma (HIT and RIN) cells and $\mathrm{J}-774$ cells share a common mechanism for alloxandependent cytotoxicity involving extracellular reduction- and autoxidation of alloxan with the formation of hydrogen peroxide, which, in turn, initiates intralysosomal, iron-catalysed reactions that result in lysosomal destabilization and leakage of damaging lysosomal contents (see schematic Figure 7). The large differences between insulinoma and J-774 cells with respect to their sensitivity to either alloxan/cysteine or hydrogen peroxide may be at least partly explained by their different capacities to degrade hydrogen peroxide due to differences in the activity of 
glutathione peroxidase. It cannot be excluded, however, that differences in the amounts of lysosomal reactive iron among the cell types are also of importance.

Acknowledgements. HIT and RIN cells were kindly donated by Department of Medical Cell Biology, Uppsala University, Uppsala, and Division of Toxicology, Karolinska Institute, Stockholm, Sweden. We thank Ms. I.Svensson, Ms. K. Roberg and Mr. U. Johansson for technical assistance. This study was supported by the Swedish Medical Research Council, grant No. 4481.

\section{References}

1. Webb JL (1966) Alloxan. In: Webb JL (ed) Enzyme and metabolic inhibitors vol.III. Academic Press, New York, pp 367-419

2. Wellmann KF, Volk BW, Lazarus SS (1967) Ultrastructural pancreatic beta-cell changes in rabbits after small and large doses of alloxan. Diabetes 16: 242-251

3. Heikkila RE, Winston B, Cohen G, Barden H (1976) Alloxan-induced diabetes - evidence for hydroxyl radical as a cytotoxic intermediate. Biochem Pharmacol 25: 10851092

4. Fischer LJ, Hamburger SA (1980) Inhibition of alloxan action in isolated pancreatic islets by superoxide dismutase, catalase, and a metal chelator. Diabetes 29: 213-216

5. Boquist L (1980) A new hypothesis for alloxan diabetes. Acta Path Microbiol Scand Sect A 88: 202-209

6. Malaisse WJ, Malaisse-Lagae F, Sener A, Pipeleers DG (1982) Determinants of the selective toxicity of alloxan to the pancreatic $\beta$ cell. Proc Natl Acad Sci USA 79: 927-930

7. Takasu N, Komiya I, Asawa T, Nagasawa Y, Yamada T (1991) Streptoxocin- and alloxan-induced $\mathrm{H}_{2} \mathrm{O}_{2}$ generation and DNA fragmentation in pancreatic islets. $\mathrm{H}_{2} \mathrm{O}_{2}$ as mediator for DNA fragmentation. Diabetes 40: 11411145

8. Watala C, Budziejewska A, Jozwiak Z (1989) Alloxan-induced alterations in composition and dynamics of red blood cell membranes. I. Effect of alloxan on intact red blood cells and isolated erythrocyte membranes. Biochem Pharmacol 38: 1793-1798

9. Harman AW, Fischer LJ (1982) Alloxan toxicity in isolated rat hepatocytes and protection by sugars. Biochem Pharmacol 31: 3731-3736

10. Ishibashi $\mathrm{F}$, Howard BV (1981) Alloxan and $\mathrm{H}_{2} \mathrm{O}_{2}$ action on glucose metabolism in cultured fibroblasts. Generation of oxygen-containing free radicals as a mechanism of alloxan action. J Biol Chem 256: 12134-12139

11. Sagström S, Scarlett SM, Sagulin G-B, Roomans GM (1987) Early effects of alloxan on rat submandibular gland. J Submicrosc Cytol 19: 555-559

12. Zhang H, Zdolsek J, Brunk U (1991) Effects of alloxan and reducing agents on macrophages in culture. APMIS 99: $1038-1048$

13. Zhang H, Gao G, Brunk U (1992) Extracellular reduction of alloxan results in oxygen radical-mediated attack on plasma and lysosomal membranes. APMIS 100: 317-325

14. Zhang H, Zdolsek J, Brunk U (1992) Alloxan cytotoxicity involves lysosomal damage. APMIS 100: 309-316

15. Zhang H, Brunk U (1993) Alloxan cytotoxicity is highly potentiated by plasma membrane- and lysosomal-associated iron - a study on a model system of cultured J-774 cells. Diabetologia 36: 707-715
16. Lagercrantz C, Yhland M (1963) Free radicals in the reaction of alloxan with glutathione and ascorbic acid. Acta Chem Scand 17: 1677-1682

17. Deamer DW, Heikkila RE, Panganamala RV, Cohen G, Cornwell DG (1971) The alloxan-dialuric acid cycle and the generation of hydrogen peroxide. Physiol Chem Phys 3: $426-430$

18. Grankvist K, Marklund SL (1986) Effect of extracellularly generated free radicals on the plasma membrane permeability of isolated pancreatic $\beta$-cells. Int $\mathrm{J}$ Biochem 18 : $109-113$

19. Winterbourn CC, Munday R (1989) Glutathione-mediated redox cycling of alloxan. Mechanisms of superoxide dismutase inhibition and of metal-catalyzed OH. formation. Biochem Pharmacol 38: 271-277

20. Granvist K, Marklund S, Sehlin J, Täljedal I-B (1979) Superoxide dismutase, catalase and scavengers of hydroxyl radical protect against the toxic action of alloxan on pancreatic islet cells in vitro. Biochem $\mathrm{J} 182: 17-25$

21. Starke PE, Gilbertson JD, Farber JL (1985) Lysosomal origin of the ferric iron required for cell killing by hydrogen peroxide. Biochem Biophys Res Commun 133: 371-379

22. Zdolsek JM, Zhang H, Roberg K, Brunk UT (1993) $\mathrm{H}_{2} \mathrm{O}_{2}$ mediated damage to lysosomal membranes of J-774 cells. Free Radic Res Commun 18: 71-85

23. Halliwell B, Gutteridge JM (1984) Oxygen toxicity, oxygen radicals, transition metals and disease. Biochem 18: 1-14

24. Lloyd JB, Cable H, Rice-Evans C (1991) Evidence that deferoxamine cannot enter cells by passive diffusion. Biochem Pharmacol 41: 1361-1363

25. Chance B, Sies H, Boveris A (1979) Hydrogen peroxide metabolism in mammalian organs. Physiol Rev 59: 527-605

26. Santerre RF, Cook RA, Crisel RMD et al. (1981) Insulin synthesis in a colonial cell line of simian virus 40 -transformed hamster pancreatic beta cells. Proc Natl Acad Sci USA 78: 4339-4343

27. Chick WL, Warren S, Chute RN, Like AA, Lauris V, Kitchen $\mathbf{K}$ (1977) A transplantable insulinoma in the rat. Proc Natl Acad Sci USA 74: 628-632

28. Tennant JR (1964) Evaluation of the trypan blue technique for determination of cell viability. Transplantation 2: 685694

29. Robbins E, Marcus PI (1963) Dynamics of acridine orangecell interaction. I. Interrelationships of acridine orange particles and cytoplasmic reddening. J Cell Biol 18: 237-250

30. Rundquist I, Olsson M, Brunk U (1984) Cytofluorometric quantitation of acridine orange uptake by cultured cells. Acta Pathol Microbiol Immunol Scand [A] 92: 303-309

31. Panus PC, Radi R, Chumley PH, Lillard RH, Freeman BA (1993) Detection of $\mathrm{H}_{2} \mathrm{O}_{2}$ release from vascular endothelial cells. Free Radic Biol Med 14: 217-223

32. Honegger CG, Langemann H, Krenger W, Kempf A (1989) Liquid chromatographic determination of common watersoluble antioxidants in biological samples. J Chromatogr 487: $463-468$

33. Lowry OH, Rosebrough NJ, Farr AL, Randall RJ (1951) Protein measurement with the folin phenol reagent. J Biol Chem 193: 265-273

34. Günzler WA, Flohé L (1989) Glutathione peroxidase. In: Greenwald RA (ed) Handbook of methods for oxygen radical research. CRC Press, Boca Raton, pp 285-290

35. Worthington DJ, Rosemeyer (1974) Human glutathione reductase: purification of the crystalline enzyme from erythrocytes. Eur J Biochem 48: 167-177

36. Beer RF, Sizer IW (1952) A spectrophotometric method for measuring the breakdown of hydrogen peroxide by catalase. J Biol Chem 195: 133-140 